\title{
PD-1 and PD-L1 expression on PBMC subsets in normal individuals and cancer patients
}

\author{
Lauren Lepone ${ }^{1 *}$, Renee N Donahue1, Italia Grenga ${ }^{1}$, James L Gulley², Christopher R Heery ${ }^{1}$, Ravi A Madan ${ }^{3}$, \\ Jeffrey Schlom", Benedetto Farsaci ${ }^{1}$ \\ From Society for Immunotherapy of Cancer 29th Annual Meeting \\ National Harbor, MD, USA. 6-9 November 2014
}

\section{Purpose}

Immunotherapies aiming to interfere with the immune checkpoint molecule PD-1 (programmed death-1) and its ligand PD-L1 are currently being investigated in several clinical trials to treat cancer patients. The PD-1 pathway is one of the ways cancer cells evade immune-mediated killing. As little is known about the expression of PD-1 and PD-L1 in cancer patients compared to normal individuals, the aim of this study was to assess PBMC subsets for expression of these markers.

\section{Methods}

Twelve immune cell subsets were analyzed by flow-cytometry in 22 cancer patients and 16 normal individuals. The cancer patients consisted of 1 anal, 2 breast, 4 colon, 1 esophageal, 2 mesothelioma, 1 neuroendocrine, 1 non-small cell lung, 1 ovarian, 5 pancreatic, 3 renal cell and 1 squamous cell tracheal cancer patients. The subsets analyzed were CD4 and CD8 T cells, B cells, conventional dendritic cells (cDC), plasmacytoid DC (pDC), natural killer cells (NK), natural killer T cells (NKT), myeloid derived suppressor cell (MDSC), mono-

\begin{tabular}{|c|c|c|c|c|c|c|c|c|c|c|c|c|}
\hline & CD4 & CDS & B cell & Treg & $\mathrm{CDC}$ & $\mathrm{pDC}$ & NK & NKT & MDSC & mMDSC & gMDSC & $\begin{array}{l}\text { Lin: } \\
\text { MDSC }\end{array}$ \\
\hline $\begin{array}{c}\text { Subset } \\
(\% \text { PBMC) }\end{array}$ & $=$ & $=$ & $\downarrow$ & $=$ & $=$ & $=$ & $=$ & $=$ & $=$ & $\downarrow$ & $\uparrow$ & $\hat{\uparrow}$ \\
\hline $\begin{array}{c}\text { PD-1- } \\
\text { (\% parent) }\end{array}$ & $\uparrow$ & $=$ & $=$ & $\uparrow$ & $\downarrow$ & $\uparrow$ & $=$ & $=$ & $\uparrow$ & $=$ & $=$ & $=$ \\
\hline $\begin{array}{c}\text { PD-L1- } \\
\text { (\% parent) }\end{array}$ & $=$ & $=$ & $=$ & $\uparrow$ & $=$ & $\uparrow$ & $\uparrow$ & $=$ & $\uparrow$ & $=$ & $=$ & $\uparrow$ \\
\hline $\begin{array}{l}\uparrow, \text { increase fre } \\
\text { PBMC, perip } \\
\text { CD } 56 \text { CD 1c } \\
\text { (CD14-CD15 }\end{array}$ & $\begin{array}{l}\text { vency in } \\
\text { al blood } \\
303-; 1 \\
\text { (DSC); I }\end{array}$ & $\begin{array}{l}\text { anoerpat } \\
\text { monomec } \\
\text { K(CD3 } \\
\text { in:MDSC }\end{array}$ & $\begin{array}{l}\text { ents comp } \\
\text { ear cell; B } \\
\text { D56); NK } \\
\text { (CD 14CD }\end{array}$ & $\begin{array}{l}\text { red to no } \\
\text { ells (CD } \\
\text { (CD3- } \\
5 \text { MDSC }\end{array}$ & $\begin{array}{l}\mathrm{mal} \text { ind } \\
9-\mathrm{T}_{\mathrm{r}} \\
\left.\mathrm{D} 56^{-}\right) ;\end{array}$ & $\begin{array}{l}\text { duals; } \downarrow \text {, } \\
\text { (CD4-C) } \\
\text { DSC (CI }\end{array}$ & $\begin{array}{l}\text { ecreas } \\
25-\mathrm{Fo} \\
\mathrm{lb}-\mathrm{HI}\end{array}$ & $\begin{array}{l}=, \mathrm{noch} \\
3-\mathrm{CD} 12 \\
\mathrm{DR} \cdot \mathrm{CD}\end{array}$ & $\begin{array}{l}\text { ge } \\
; c D C(C D \\
-) ; \text { mMDS }\end{array}$ & $\begin{array}{l}\mathrm{CD} 56 \mathrm{CD} 1 \mathrm{c} \\
\text { (CD14-CD) }\end{array}$ & $\begin{array}{l}\text { D303); } \mathrm{pD} \\
\mathrm{MDSC}) ; \mathrm{gN}\end{array}$ & $\begin{array}{l}\text { (CD3. } \\
\text { SC }\end{array}$ \\
\hline
\end{tabular}

Figure 1 Differences in PBMC subsets and PD-1 and PD-L1 expression in cancer patients at baseline and normal individuals.

'Laboratory of Tumor Immunology and Biology, $\mathrm{CCR}, \mathrm{NCl}, \mathrm{NIH}$, Bethesda,

MD, USA

Full list of author information is available at the end of the article 
cytic MDSC (mMDSC), granulocytic MDSC (gMDSC), and lineage-negative MDSC (Lin-MDSC). We also analyzed surface expression of PD-1 (clone MIH4) and PDL-1 (clone MIH1). See Figure 1.

\section{Results}

Compared to normal subjects, cancer patients had some PBMC subsets with changes in frequency but no differences in PD-1 and PD-L1 expression (i.e., B cells, mMDSCs, and gMDSCs). Other subsets showed changes in PD-1 and PD-L1 expression without differences in the frequency of the subset (i.e., CD4, Tregs, cDCs, pDCs, NK, and MDSCs). Lin-MDSCs presented at a higher frequency and greater PD-L1 positivity.

\section{Conclusions}

Understanding the differences of PBMC immune subsets between normal subjects and cancer patients, and the surface expression of PD-1 and PD-L1, can provide insights as to which immune subsets can be targeted by therapies aimed at interfering with the PD-1 pathway in cancer patients.

\section{Authors' details}

'Laboratory of Tumor Immunology and Biology, CCR, NCl, NIH, Bethesda, MD, USA. ${ }^{2} \mathrm{CCR}, \mathrm{NCl}, \mathrm{NIH}$, Bethesda, MD, USA. ${ }^{3}$ Genitourinary Malignancies Branch, CCR, NCl, NIH, Bethesda, MD, USA.

Published: 6 November 2014

doi:10.1186/2051-1426-2-S3-P152

Cite this article as: Lepone et al:: PD-1 and PD-L1 expression on PBMC subsets in normal individuals and cancer patients. Journal for

ImmunoTherapy of Cancer 2014 2(Suppl 3):P152.

Submit your next manuscript to BioMed Central and take full advantage of:

- Convenient online submission

- Thorough peer review

- No space constraints or color figure charges

- Immediate publication on acceptance

- Inclusion in PubMed, CAS, Scopus and Google Scholar

- Research which is freely available for redistribution 